\author{
Dariusz Kużelewski \\ Uniwersytet w Białymstoku \\ d.kuzelewski@uwb.edu.pl
}

\title{
Efektywność mediacji w postępowaniach karnych prowadzonych w latach 2011-2014 przed Sądem Rejonowym w Białymstoku w świetle badań aktowych
}

\author{
The Effectiveness of Victim-Offender Mediation in Criminal Proceedings Carried Out \\ in 2011-2014 in the District Court of Białystok in the Light of Files Research
}

\begin{abstract}
This article is based on the results of scientific research conducted within a project entitled „The pilot implementation of the Community Court model in Poland as an institutional bridge between the judiciary, local government authorities and social organizations to facilitate the implementation of restorative justice in practice". The project was funded by the National Centre for Research and Development under the „Social Innovations” programme in accordance with Agreement No. /IS-1/039/ NCBR/2014. Within the project, fifty court cases, which had previously been referred to victim-offender mediation, were examined. All of them were conducted before the Third Criminal Department of the District Court in Bialystok in 2011-2014. The decisive criterion was the date of the court's decision to refer the case to victim-offender mediation. The ratio of settlements concluded in the course of victimoffender mediation in criminal cases conducted before the District Court of Białystok, is about 10-30\% lower in comparison to the national average in each of the years studied. The types of crime which are most frequently referred to mediation proceedings in the District Court of Białystok, and in other Polish courts, do not differ. Crimes against life and health, honour and personal inviolability, the family and guardianship, property, as well as against freedom, are the most common. Motions for victim-offender mediation are usually filed by counsels for the defence and by the accused themselves, and subsequently the court. The best results in mediation settlements are reached in cases involving a joint initiative of the parties. In cases in which settlement was concluded, the court most frequently applied a conditional discontinuance of proceedings or imprisonment with conditional suspension of its execution. The failure of mediation resulted mainly from the lack of agreement by the parties, and subsequently from the absence or refusal to participate in mediation by the accused or the victim(s). Mediation completed with a settlement effectively prevents lodging an appeal against the sentence of the court of first instance. An appeal was lodged in only $12.5 \%$ of such cases.
\end{abstract}

Keywords: victim-offender mediation, effectiveness, criminal proceedings

Słowa kluczowe: mediacja między ofiarą i sprawcą, efektywność, postępowanie karne 
Niniejszy artykuł przedstawia efekty badań przeprowadzonych $\mathrm{w}$ ramach projektu pt. „Pilotażowe wdrożenie modelu «Community Court» w Polsce jako instytucjonalnego pomostu pomiędzy wymiarem sprawiedliwości, organami samorządowymi i organizacjami społecznymi ułatwiającego realizację sprawiedliwości naprawczej w praktyce"1. Jednym z założonych w projekcie działań było wykonanie badań aktowych 50 spraw sądowych, które skierowano do postępowania mediacyjnego. Głównym celem zaś była ocena stanu i barier szerszego wykorzystania metod sprawiedliwości naprawczej przez wymiar sprawiedliwości oraz udziału czynnika społecznego w postępowaniu karnym. Za czynnik społeczny uznano tu obok ławników, przedstawiciela organizacji społecznej jako tzw. rzecznika interesu społecznego oraz podmiotu udzielającego poręczenia społecznego jako środka zapobiegawczego, jak również mediatora prowadzącego mediację między pokrzywdzonym a oskarżonym. Celem cząstkowym, dotyczącym bezpośrednio badań aktowych, było zdiagnozowanie wybranych aspektów postępowania karnego w odniesieniu do mediacji i jej wyników. Ze względu na charakter i ograniczenia redakcyjne, w niniejszym artykule przedstawiono tylko niektóre poddane badaniom zagadnienia związane $\mathrm{z}$ efektywnością postępowania mediacyjnego oraz wpływającymi na nią czynnikami. Pominięto również opis instytucji mediacji w polskim prawie karnym, jako że tematyka ta jest przedmiotem wielu powszechnie dostępnych opracowań naukowych².

Do badań wytypowano sprawy prowadzone w III Wydziale Karnym Sądu Rejonowego w Białymstoku. Zakres czasowy objął lata 2011, 2012, 2013 oraz I półrocze 2014 roku. Sprawy wyselekcjonowano, sięgając do wykazu mediacji MED za wyżej wymieniony okres, gdzie decydującym kryterium była data postanowienia sądu o skierowaniu pokrzywdzonego i oskarżonego do postępowania mediacyjnego.

Tabela 1. Liczba przeprowadzonych mediacji i ich wyniki w poszczególnych latach

\begin{tabular}{|c|c|c|c|c|c|c|}
\hline \multirow{2}{*}{ Rok } & \multicolumn{2}{|c|}{$\begin{array}{c}\text { Sprawy skierowane } \\
\text { do mediacji }\end{array}$} & \multicolumn{2}{c|}{$\begin{array}{c}\text { Mediacje zakończone } \\
\text { ugodą }\end{array}$} & \multicolumn{2}{c|}{ Mediacje bez ugody } \\
\cline { 2 - 7 } & liczba & $\%$ & liczba & $\%$ & liczba & $\%$ \\
\hline 2011 & 16 & 32 & 7 & 43,75 & 9 & 56,25 \\
\hline 2012 & 11 & 22 & 4 & 36,4 & 7 & 63,6 \\
\hline 2013 & 14 & 28 & 8 & 57,2 & 6 & 42,8 \\
\hline
\end{tabular}

1 Projekt sfinansowany został przez Narodowe Centrum Badań i Rozwoju w ramach programu „Innowacje Społeczne" zgodnie z umową nr /IS-1/039/NCBR/2014.

2 Zob. m.in. publikacje wydane w ostatnich latach: L. Mazowiecka (red.), Mediacja karna jako forma sprawiedliwości naprawczej, Warszawa 2011; E. Bieńkowska, O unormowaniu mediacji w sprawach karnych, „Prokuratura i Prawo" 2012, nr 1, s. 19-36; L. Mazowiecka (red.), Mediacja w praktyce prokuratorskiej - dziś i jutro, Warszawa 2012; L. Mazowiecka (red.), Mediacja karna jako instytucja ważna dla pokrzywdzonego, Warszawa 2013; D. Szumiło-Kulczycka, Proces karny a idea sprawiedliwości naprawczej, (w:) P. Hofmański (red.), System prawa karnego procesowego. Tom I. Cz. 2. Zagadnienia ogólne, Warszawa 2014, s. 365-415; J. Czapska, M. SzelągDylewski (red.), Mediacje w prawie, Kraków 2014; L. Mazowiecka (red.), Unijne standardy programów sprawiedliwości naprawczej, Warszawa 2015. 
Efektywność mediacji w postępowaniach karnych prowadzonych...

\begin{tabular}{|c|c|c|c|c|c|c||}
\hline I półrocze 2014 & 9 & 18 & 5 & 55,6 & 4 & 44,4 \\
\hline Łącznie & 50 & 100 & 24 & 48 & 26 & 52 \\
\hline
\end{tabular}

Źródło: Opracowanie własne.

W analizowanym okresie corocznie do mediacji kierowano kilkanaście spraw (w 2014 r. do końca września w wykazie MED odnotowano 13 spraw). Biorąc pod uwagę liczbę tych spraw (po 3254 sprawy w 2011 i 2012 r., 3696 spraw 2013 r. oraz 3770 spraw w 2014 r. $^{3}$ ) oraz liczbę sądów rejonowych i okręgowych w Polsce (ponad 360), III Wydział Karny Sądu Rejonowego w Białymstoku statystycznie plasuje się nieco powyżej średniej liczby spraw skierowanych do mediacji przypadającej na jeden sąd. Na liczbę spraw potencjalnie nadających się do mediacji może jednak rzutować fakt, że prokuratury Apelacji Białostockiej bardzo często, w stosunku do pozostałych apelacji, kierują prowadzone przez siebie sprawy do mediacji już na etapie postępowania przygotowawczego ${ }^{4}$, zatem pula takich spraw zostaje w dużym stopniu wyczerpana w postępowaniu przygotowawczym i jest siłą rzeczy mniejsza w postępowaniu sądowym. Tym bardziej należy wysoko ocenić ponadprzeciętną liczbę spraw kierowanych corocznie do mediacji przez Sąd Rejonowy w Białymstoku w stosunku do średniej ogólnopolskiej.

Efektywność mediacji rozumiana jako zawarcie w jej wyniku ugody między pokrzywdzonym a oskarżonym była zróżnicowana. Jednak w każdym roku objętym badaniem plasowała się ona niżej od ogólnopolskiej średniej, utrzymującej się od lat na poziomie między 60 a 70\% postępowań mediacyjnych zakończonych ugodą $\mathrm{w}$ stosunku do wszystkich spraw skierowanych do mediacji ${ }^{5}$. Łącznie wśród 50 przebadanych spraw liczba mediacji zakończonych ugodą stanowi niemal połowę wszystkich

3 Dane statystyczne Departamentu Sądów, Organizacji i Analiz Wymiaru Sprawiedliwości Ministerstwa Sprawiedliwości, http://ms.gov.pl/pl/dzialalnosc/mediacje/publikacje-akty-prawne-statystyki/ (data dostępu: 19 grudnia 2016 r.).

$4 \quad$ Zob. dane w: D. Kużelewski, Mediacja w procesie karnym w opinii sędziów i prokuratorów - wybrane zagadnienia, (w:) C. Kulesza (red.), Ocena funkcjonowania porozumień procesowych w praktyce wymiaru sprawiedliwości, Warszawa 2009, s. 258-259; E. Wildner, Stosowanie mediacji w postępowaniu przygotowawczym - wybrane zagadnienia, (w:) J. Czapska, M. Szeląg-Dylewski (red.), Mediacje w prawie, Kraków 2014, s. 289; Sprawozdania Prokuratora Generalnego z rocznej działalności prokuratury w roku 2010, 2011, 2012, 2013, 2014 i 2015, http:// pk.gov.pl/sprawozdania/sprawozdania-prokuratora-generalnego-1133-2.html (data dostępu: 19 grudnia 2016 r.). Odsetek spraw skierowanych w postępowaniu przygotowawczym przez prokuratury Apelacji Białostockiej do mediacji w stosunku do całego kraju wyniósł w omawianym okresie: w 2011 r. 57,5\%, w 2012 r. 60,3\%, w 2013 r. $57,8 \%$ oraz w 2014 r. 57,1\%. Najnowsze dane za 2015 r. wskazują na znaczny spadek tego wskaźnika do $48,7 \%$.

5 Dane statystyczne Departamentu Sądów, Organizacji i Analiz Wymiaru Sprawiedliwości Ministerstwa Sprawiedliwości, http://ms.gov.pl/pl/dzialalnosc/mediacje/publikacje-akty-prawne-statystyki/ (data dostępu: 19 grudnia 2016 r.). Wyższe współczynniki zawartych ugód niż w Białymstoku osiągano również w czterech krakowskich sądach rejonowych w latach 2010-2011: odpowiednio 61\% z łącznej liczby 172 spraw skierowanych do mediacji oraz 53\% z 211 spraw - zob. M. Chalimoniuk-Zięba, G. Oklejak, Stosowanie postępowania mediacyjnego w sprawach karnych w latach 2010-2011, analiza na podstawie badań aktowych przeprowadzonych w krakowskich sądach rejonowych, (w:) J. Czapska, M. Szeląg-Dylewski (red.), Mediacje w prawie, Kraków 2014, s. 324. Przykład znacznie niższego współczynnika $(29,9 \%)$ w starszych badaniach przeprowadzonych w Warszawie - zob. M. Mendelska-Stec, Wyniki badań. Funkcjonowanie instytucji mediacji w Polsce, „Mediator” 2005, nr 3, s. 52-53. 
postępowań mediacyjnych ${ }^{6}$. Należy zwrócić uwagę, że w czterech sprawach, w których wobec rozbieżności stanowisk ugody nie zawarto, doszło do przeproszenia pokrzywdzonych oraz przyjęcia przeprosin, zaś w dwóch kolejnych takich sprawach wyrażono obopólną gotowość pojednania.

Tabela 2. Liczba przeprowadzonych mediacji i ich wyniki według trybów postępowania

\begin{tabular}{|l|c|c|c|c|c|c|}
\hline \multirow{2}{*}{ Tryb postępowania } & \multicolumn{2}{|c|}{$\begin{array}{c}\text { Sprawy skierowane } \\
\text { do mediacji }\end{array}$} & \multicolumn{2}{c|}{$\begin{array}{c}\text { Mediacje zakończone } \\
\text { ugodą }\end{array}$} & \multicolumn{2}{c|}{ Mediacje bez ugody } \\
\cline { 2 - 7 } & liczba & $\%$ & liczba & $\%$ & liczba & $\%$ \\
\hline Zwyczajny & 5 & 10 & 3 & 60 & 2 & 40 \\
\hline Uproszczony & 23 & 46 & 14 & 60,9 & 9 & 39,1 \\
\hline $\begin{array}{l}\text { Uproszczony ze } \\
\text { zmianą na zwyczajny }\end{array}$ & 9 & 18 & 3 & 33,3 & 6 & 66,7 \\
\hline Prywatnoskargowy & 13 & 26 & 4 & 30,8 & 9 & 69,2 \\
\hline Łącznie & 50 & 100 & 24 & 48 & 26 & 44 \\
\hline
\end{tabular}

Źródło: Opracowanie własne.

Mimo że mediacja (alternatywnie do posiedzenia pojednawczego) jest obowiązkowym elementem postępowania prywatnoskargowego, $\mathrm{w}$ trybie tym toczyło się zaledwie $26 \%$ spraw, które skierowano do postępowania mediacyjnego. Uczestnicy takich mediacji byli również najmniej ugodowi - jedynie 4 z 13 (30,8\%) postępowań mediacyjnych w trybie prywatnoskargowym zakończyły się ugodą. Znaczna większość spraw z udziałem mediacji toczyła się w funkcjonującym wówczas jeszcze w procesie karnym postępowaniu uproszczonym, przy czym w części spraw doszło do zmiany trybu na zwyczajny. W sprawach zakończonych w trybie uproszczonym odnotowano najwyższy ze wszystkich trybów odsetek ugód - 60,9\%.

Tabela 3. Liczba przeprowadzonych mediacji i ich wyniki według rodzajów przestępstw

\begin{tabular}{||l|c|c|c|c|c|c||}
\hline \multirow{2}{*}{\multicolumn{1}{c|}{ Rodzaj przestępstwa }} & \multicolumn{2}{c|}{$\begin{array}{c}\text { Sprawy skierowane } \\
\text { do mediacji }\end{array}$} & \multicolumn{2}{c|}{$\begin{array}{c}\text { Mediacje zakoń- } \\
\text { czone ugodą }\end{array}$} & \multicolumn{2}{c|}{$\begin{array}{c}\text { Mediacje bez } \\
\text { ugody }\end{array}$} \\
\cline { 2 - 7 } & liczba & $\%$ & liczba & $\%$ & liczba & $\%$ \\
\hline Przeciwko życiu i zdrowiu & 19 & 38 & 4 & 21,1 & 15 & 78,9 \\
\hline $\begin{array}{l}\text { Przeciwko bezpieczeństwu } \\
\text { w komunikacji }\end{array}$ & 2 & 4 & 2 & 100 & 0 & 0 \\
\hline
\end{tabular}

6 Jedna ze spraw zakwalifikowanych jako skutkująca brakiem ugody w rzeczywistości była bardziej skomplikowana. Doszło do mediacji między pokrzywdzoną a trojgiem oskarżonych zakończonej przeproszeniem oraz ugodą co do odszkodowania i zadośćuczynienia, po czym sprawę z ich udziałem wyłączono do odrębnego rozpoznania. Pozostałych dwóch oskarżonych nie stawiło się na spotkanie mediacyjne, zatem w ich przypadku mediacja zakończyła się niepowodzeniem. 
Efektywność mediacji w postępowaniach karnych prowadzonych...

\begin{tabular}{|l|c|c|c|c|c|c||}
\hline Przeciwko wolności & 4 & 8 & 1 & 25 & 3 & 75 \\
\hline Przeciwko rodzinie i opiece & 8 & 16 & 7 & 87,5 & 1 & 12,5 \\
\hline $\begin{array}{l}\text { Przeciwko czci i nietykalności } \\
\text { cielesnej }\end{array}$ & 9 & 18 & 4 & 44,4 & 5 & 55,6 \\
\hline $\begin{array}{l}\text { Przeciwko prawom osób wykonują- } \\
\text { cych pracę zarobkową }\end{array}$ & 1 & 2 & 1 & 100 & 0 & 0 \\
\hline Przeciwko mieniu & 7 & 14 & 5 & 71,4 & 2 & 28,6 \\
\hline Łącznie & 50 & 100 & 24 & 48 & 26 & 52 \\
\hline
\end{tabular}

Źródło: Opracowanie własne.

Na podstawie kwalifikacji prawnych czynów zarzuconych oskarżonym ustalono, jakie rodzaje przestępstw najczęściej kierowane były do mediacji, a zarazem które z nich ze względu na efekt końcowy najlepiej nadają się do procedury mediacyjnej. Jako że w części spraw zarzut obejmował dwa i więcej zbiegających się przepisów, dla uproszczenia klasyfikowano takie sytuacje w kategorie, biorąc pod uwagę przy ich wyodrębnianiu główny aspekt czynu, np. znęcanie się (art. $207 \$ 1$ k.k.) w zbiegu z uszkodzeniem ciała (art. $157 \$ 1$ lub $\$ 2$ k.k.) lub naruszeniem nietykalności cielesnej (art. $217 \$ 1$ k.k.) zaliczono do przestępstw przeciwko rodzinie i opiece, pozbawienie wolności (art. $189 \$ 1$ k.k.) w zbiegu z uszkodzeniem ciała (art. $157 \$ 1$ lub $\$ 2$ k.k.), pobiciem (art. $158 \$ 1$ k.k.) lub naruszeniem nietykalności cielesnej (art. $217 \$ 1$ k.k.) do przestępstw przeciwko wolności. Pozwala to dokonać konstatacji, że wśród wszystkich spraw przekazanych w omawianym okresie do postępowania mediacyjnego większość z nich (38\%) stanowiły czyny przeciwko życiu i zdrowiu (uszkodzenia ciała $\mathrm{z}$ art. $157 \$ 1$ lub $\$ 2$ k.k. oraz pobicia $\mathrm{z}$ art. $158 \$ 1 \mathrm{k} . \mathrm{k}$.), a następnie przestępstwa przeciwko czci i nietykalności cielesnej (zniesławienie - art. $216 \$ 1$ k.k., znieważenie - art. $206 \$ 1$ k.k. oraz naruszenie nietykalności cielesnej - art. 217 $\$ 1$ k.k.), przeciwko rodzinie i opiece (znęcanie się - art. $207 \$ 1$ k.k.) oraz przeciwko mieniu (rozbój - art. $280 \$ 1$ k.k., zniszczenie rzeczy - art. $288 \$ 1$ k.k.). Dane powyższe są potwierdzeniem wniosków płynących z badań prowadzonych przez innych autorów zarówno w odniesieniu do mediacji w postępowaniu przygotowawczym ${ }^{7}$, jak i sądowym ${ }^{8}$. Wymienione wyżej rodzaje i typy przestępstw w różnych proporcjach stanowią główny przedmiot postępowań mediacyjnych, jak też akceptowane są w li-

7 Zob. E. Wildner, Stosowanie..., op. cit., s. 291.

8 Zob. dane dotyczące postępowań mediacyjnych w sądach okręgu lubelskiego w latach 1998-2002 - R. Kaszczyszyn, Rozwój i sytuacja mediacji w Polsce na przykładzie ośrodka lubelskiego, „Mediator” 2003, nr 2, s. 40. Kolejne badania przeprowadzone w Lublinie wskazują, że w tamtejszych sądach w latach 2006-2011 (I półrocze) do postępowania mediacyjnego były kierowane najczęściej sprawy dotyczące przestępstw przeciwko rodzinie i opiece, wolności, życiu i zdrowiu oraz mieniu - zob. G.A. Skrobotowicz, Mediacja karna - studium przypadku, (w:) J. Czapska, M. Szeląg-Dylewski (red.), Mediacje w prawie, Kraków 2014, s. 305-308. W sądach krakowskich w latach 2010-2011 kolejność ta kształtowała się następująco: przestępstwa przeciwko rodzinie i opiece, życiu i zdrowiu, mieniu, czci i nietykalności cielesnej, wolności oraz bezpieczeństwu w komunikacji - zob. M. Chalimoniuk-Zięba, G. Oklejak, Stosowanie postępowania mediacyjnego..., op. cit., s. 326. 
teraturze i wśród praktyków jako czyny najlepiej nadające się do pojednania i ugody przed mediatorem ${ }^{9}$.

Odrzucając ze względu na pojedyncze przypadki przestępstwa przeciwko bezpieczeństwu w komunikacji oraz przeciwko prawom osób wykonujących pracę zarobkową, najwyższą efektywność postępowań mediacyjnych odnotowano w przypadku przestępstw przeciwko rodzinie i opiece (ugody w 87,5\% takich przypadków) oraz przeciwko mieniu $(71,4 \%)$. Najniższy współczynnik zawartych ugód miał miejsce w przypadku przestępstw przeciwko życiu i zdrowiu (zaledwie 21,1\%).

Tabela 4. Liczba przeprowadzonych mediacji i ich wyniki według podmiotów wnioskujących o mediację

\begin{tabular}{|c|c|c|c|c|c|c|}
\hline \multirow{2}{*}{$\begin{array}{c}\text { Podmiot wnioskujący } \\
\text { lub informujący o mediacji }\end{array}$} & \multicolumn{2}{|c|}{$\begin{array}{l}\text { Sprawy skierowane } \\
\text { do mediacji }\end{array}$} & \multicolumn{2}{|c|}{$\begin{array}{c}\text { Mediacje zakończone } \\
\text { ugodą }\end{array}$} & \multicolumn{2}{|c|}{ Mediacje bez ugody } \\
\hline & liczba & $\%$ & liczba & $\%$ & liczba & $\%$ \\
\hline Sąd (za zgodą stron) & 10 & 20 & 3 & 30 & 7 & 70 \\
\hline Wniosek oskarżonego & 10 & 20 & 6 & 60 & 4 & 40 \\
\hline Wniosek pokrzywdzonego & 2 & 4 & 0 & 0 & 2 & 100 \\
\hline Wniosek obu stron & 6 & 12 & 6 & 100 & 0 & 0 \\
\hline Wniosek obrońcy & 14 & 28 & 5 & 35,7 & 9 & 64,3 \\
\hline $\begin{array}{l}\text { Wniosek pełnomocnika } \\
\text { pokrzywdzonego }\end{array}$ & 3 & 6 & 0 & 0 & 3 & 100 \\
\hline $\begin{array}{l}\text { Wniosek prokuratora (za } \\
\text { zgodą stron) }\end{array}$ & 1 & 2 & 1 & 100 & 0 & 0 \\
\hline Brak danych & 4 & 8 & 3 & 75 & 1 & 25 \\
\hline Łącznie & 50 & 100 & 24 & 48 & 26 & 52 \\
\hline
\end{tabular}

Źródto: Opracowanie własne.

Wnioski o mediację składali przeważnie oskarżeni i ich obrońcy (łącznie prawie połowa wszystkich przypadków). Dość aktywny był również sąd, jednak większość pouczeń dokonywana była w postępowaniu prywatnoskargowym, gdzie i tak postępowanie mediacyjne jest obligatoryjnym elementem postępowania alternatywnie do posiedzenia pojednawczego. Małe zainteresowanie wykazywali natomiast pokrzywdzeni i ich pełnomocnicy (inicjatywa łącznie tylko w 10\% przypadków).W jednej ze

9 Zob.: H. Pawlak, Mediacja w świetle danych Ministerstwa Sprawiedliwości, (w:) Konferencja naukowa: „Mediacja w polskiej rzeczywistości” (11 września 2002 r.), Warszawa 2003, s. 15; D. Wójcik, Poglądy sędziów na temat mediacji w sprawach karnych, (w:) K. Krajewski (red.), Nauki penalne wobec problemów współczesnej przestępczości. Księga jubileuszowa z okazji 70. rocznicy urodzin Profesora Andrzeja Gaberle, Warszawa - Kraków 2007, s. 560; D. Kużelewski, Mediacja w procesie karnym..., op. cit., s. 249; D. Kużelewski, Mediacja w polskim procesie karnym w ocenie prokuratorów i sędziów, (w:) C. Kulesza (red.), Porozumienia karnoprocesowe w praktyce wymiaru sprawiedliwości, Białystok 2010, s. 157-162. 
Efektywność mediacji w postępowaniach karnych prowadzonych...

spraw w aktach zaprotokołowano, że o mediację wnioskował prokurator za zgodą stron, choć na podstawie art. $23 \mathrm{a} \$ 1$ k.p.k. nie przysługuje mu taka inicjatywa ${ }^{10}$.

Nie budzi zdziwienia, że najbardziej efektywne były mediacje przeprowadzone na zgodny wniosek obu stron, gdzie we wszystkich tego typu przypadkach doszło do ugody. Już sam zgodny wniosek wskazywał na wolę pojednania i ugody. Uwagę zaś zwraca całkowite fiasko mediacji wnioskowanych przez pokrzywdzonych lub ich pełnomocników. W żadnej z pięciu takich spraw mediacja nie zakończyła się ugodą, co więcej - w trzech przypadkach w ogóle nie doszło do spotkania mediacyjnego: w jednej sprawie brak było zgody oskarżonej na mediację, w drugiej sprawie oskarżony nie stawił się, w trzeciej zaś akta zostały zwrócone sądowi przez mediatora bez przeprowadzania postępowania mediacyjnego.

Tabela 5. Liczba przeprowadzonych mediacji oraz ich wyniki według liczby pokrzywdzonych i oskarżonych biorących udział w mediacji

\begin{tabular}{|c|c|c|c|c|c|c|c|}
\hline \multirow{2}{*}{$\begin{array}{c}\text { Liczba } \\
\text { pokrzywdzonych }\end{array}$} & \multirow{2}{*}{$\begin{array}{c}\text { Liczba } \\
\text { oskarżonych }\end{array}$} & \multicolumn{2}{|c|}{$\begin{array}{c}\text { Sprawy skierowane } \\
\text { do mediacji }\end{array}$} & \multicolumn{2}{|c|}{$\begin{array}{c}\text { Mediacje } \\
\text { zakończone ugodą }\end{array}$} & \multicolumn{2}{c|}{ Mediacje bez ugody } \\
\cline { 3 - 8 } & & liczba & $\%$ & liczba & $\%$ & liczba & $\%$ \\
\hline 1 & 1 & 36 & 72 & 18 & 50 & 18 & 50 \\
\hline 1 & 2 & 5 & 10 & 2 & 40 & 3 & 60 \\
\hline 1 & 3 & 2 & 4 & 1 & 50 & 1 & 50 \\
\hline 1 & 6 & 1 & 2 & 0 & 0 & 1 & 100 \\
\hline 2 & 1 & 2 & 4 & 1 & 50 & 1 & 50 \\
\hline 2 & 2 & 2 & 4 & 1 & 50 & 1 & 50 \\
\hline 2 & 3 & 1 & 2 & 0 & 0 & 1 & 100 \\
\hline 3 & 3 & 1 & 2 & 1 & 100 & 0 & 0 \\
\hline Łącznie & - & 50 & 100 & 24 & 48 & 26 & 52 \\
\hline
\end{tabular}

Źródło: Opracowanie własne.

W zdecydowanej większości postępowania mediacyjne toczyły się w konfiguracji: jeden pokrzywdzony i jeden oskarżony (72\% wszystkich przypadków), koń-

10 Powołane wyżej badania przeprowadzone w Lublinie wskazują na nieco inne proporcje w inicjowaniu postępowań mediacyjnych: oskarżeni i ich obrońcy $(44,0 \%)$, zgodny wniosek oskarżonego i pokrzywdzonego $(34,8 \%)$, pokrzywdzeni i ich pełnomocnicy lub przedstawiciele ustawowi $(15,7 \%)$, sąd $(3,7 \%)$ oraz oskarżyciel publiczny $(1,8 \%)$ - zob. G.A. Skrobotowicz, Mediacja karna..., op. cit., s. 311. Z kolei badania krakowskie ukazują bardzo aktywną rolę sądu w tym zakresie ( $72 \%$ spraw), który nie tylko udzielał niezbędnej informacji stronom, ale również w niektórych przypadkach kierował sprawę do mediacji na posiedzeniu bez udziału stron w trybie art. 339 $\S 4$ k.p.k., cedując na mediatora obowiązek uzyskania zgody stron. Obrońcy i sami oskarżeni wnioskowali o mediację w $22 \%$ spraw, pokrzywdzeni i ich pełnomocnicy w zaledwie $3 \%$ spraw, a zgodny wniosek oskarżonego i pokrzywdzonego miał miejsce w $2 \%$ spraw - M. Chalimoniuk-Zięba, G. Oklejak, Stosowanie postępowania mediacyjnego..., op. cit., s. 324-325. 
cząc się w połowie ugodą. Konfiguracje wieloosobowe po obu stronach były znacznie rzadsze, a najciekawszy z tego punktu widzenia był przypadek zakończonej sukcesem mediacji trzech oskarżonych $z$ trzema pokrzywdzonymi, była to jednak mediacja pośrednia. Traktując zbiorczo wszystkie konfiguracje inne niż jeden pokrzywdzony i jeden oskarżony, zauważyć można niewiele niższą ich efektywność (6 mediacji zakończonych ugodą na 14 postępowań mediacyjnych, czyli 42,9\%).

Tabela 6. Treść ugody i treść orzeczenia kończącego postępowanie

\begin{tabular}{|c|c|c|c|}
\hline \multirow{2}{*}{ Treść ugody } & \multirow{2}{*}{$\begin{array}{c}\text { Treść orzeczenia kończącego } \\
\text { postępowanie karne }\end{array}$} & \multicolumn{2}{|c|}{ Mediacje zakończone ugodą } \\
\hline & & Liczba & $\%$ \\
\hline $\begin{array}{l}\text { Przeproszenie, przyjęcie } \\
\text { przeprosin }\end{array}$ & Umorzenie & 4 & 16,7 \\
\hline $\begin{array}{l}\text { Przeproszenie i inne warunki } \\
\text { niematerialne lub przeprosze- } \\
\text { nie i naprawienie szkody lub } \\
\text { zadośćuczynienie }\end{array}$ & Warunkowe umorzenie & 12 & 50 \\
\hline $\begin{array}{l}\text { Przeproszenie i inne warunki } \\
\text { niematerialne lub przeprosze- } \\
\text { nie i naprawienie szkody lub } \\
\text { zadośćuczynienie }\end{array}$ & $\begin{array}{c}\text { Skazanie na karę pozbawienia } \\
\text { wolności od } 6 \text { miesięcy do } 2 \text { lat } \\
\text { w zawieszeniu na określony czas, } \\
\text { ewentualnie naprawienie szkody } \\
\text { lub zadośćuczynienie }\end{array}$ & 8 & 33,3 \\
\hline Łącznie & - & 24 & 100 \\
\hline
\end{tabular}

Źródło: Opracowanie własne.

Tabela 6. obrazuje wpływ ugody na treść orzeczenia kończącego postępowanie karne. W czterech sprawach prywatnoskargowych wpływ ten był ewidentny, gdyż doszło w nich do pojednania, a więc sąd był zobowiązany na podstawie art. $492 \$ 1$ k.p.k. postępowanie umorzyć. W jednej z powyższych spraw mimo odczytania treści ugody zawartej przed mediatorem, sąd zastosował podstawę prawną z art. $491 \$ 1$ k.p.k. ze względu na fakt nieusprawiedliwionego niestawiennictwa na odroczone posiedzenie pojednawcze prawidłowo zawiadomionej oskarżycielki prywatnej. Pozostałe przypadki zostały w sposób uproszczony pogrupowane w dwie kategorie - sprawy zakończone warunkowym umorzeniem postępowania karnego (połowa wszystkich spraw zakończonych ugodą zawartą po przeprowadzeniu mediacji) oraz skazaniem na karę pozbawienia wolności (niekiedy łączną) i zawieszenie jej wykonania $(33,3 \%$ przypadków). Wyroki skazujące opiewały na minimum 6 miesięcy, a maksimum 2 lata pozbawienia wolności. Oba rodzaje wyroków poprzedzone były ugodami, które oprócz przeproszenia w części spraw zawierały różnorakie zobowiązania o charakterze niematerialnym, np. do niekierowania gróźb, negatywnych słów i gestów ani niepodejmowania czynów zabronionych wobec pokrzywdzonej, do niestosowania wobec pokrzywdzonej słów powszechnie uważanych za obelżywe oraz stosowania się do norm życia społecznego, do niestosowania przemocy fizycznej i psychicznej, 
niespożywania alkoholu oraz podjęcia leczenia odwykowego, do nieczynienia samowolnych prac ogrodniczych na posesji pokrzywdzonej, do rozładunku pojazdów w sposób nieuciążliwy dla wyjazdu z posesji oskarżonego, zaniechania fotografowania oraz filmowania rodziny pokrzywdzonego, do wzajemnego szacunku, nieużywania określeń wulgarnych, zgodnego życia sąsiedzkiego oraz utrzymywania kontaktów osobistych w granicach koniecznych dla życia sąsiedzkiego, do ograniczenia wzajemnych kontaktów do zwyczajowych pozdrowień, do nieoczerniania się wzajemnego. W 11 sprawach zakończonych warunkowym umorzeniem postępowania lub skazaniem na karę pozbawienia wolności w zawieszeniu ugoda mediacyjna zawierała porozumienie co do odszkodowania lub zadośćuczynienia ${ }^{11}$.

W jednej ze spraw (o prowadzenie pojazdu mechanicznego w stanie nietrzeźwości - art. 178a $\$ 1$ k.k. oraz spowodowanie w stanie nietrzeźwości wypadku drogowego skutkującego ciężkim uszczerbkiem na zdrowiu - art. $177 \$ 2$ k.k. w zw. $\mathrm{z}$ art. $178 \$ 1$ k.k.) mediacja zakończona ugodą była podstawą zgody prokuratora na dobrowolne poddanie się karze przez oskarżonego. Początkowo prokurator nie wyrażał zgody na uwzględnienie tego wniosku, zapowiadając żądanie kary 4 lat pozbawienia wolności oraz 8 lat zakazu prowadzenia pojazdów mechanicznych, ale przychylił się do wniosku obrony o przeprowadzenie mediacji. Dzięki ugodzie zawartej $\mathrm{w}$ trakcie mediacji prokurator zmienił zdanie i wraz z przedstawicielem ustawowym pokrzywdzonego zaakceptował wniosek obrony o orzeczenie kary łącznej 2 lat pozbawienia wolności z warunkowym zawieszeniem jej wykonania na okres próby wynoszący 5 lat oraz oddanie pod dozór kuratora, a także 8 lat łącznego zakazu prowadzenia pojazdów mechanicznych. Oprócz powyższego przypadku sąd uwzględnił wniosek o dobrowolne poddanie się karze przez oskarżonego w 4 sprawach, w których mediacja zakończyła się ugodą (w sprawach z mediacją bez ugody w ogóle nie odnotowano skazań w trybie art. 387 k.p.k.).

Tabela 7. Treść orzeczenia kończącego postępowanie w sprawach, w których nie osiągnięto ugody

\begin{tabular}{||l|c|c|}
\hline \multirow{2}{*}{\multicolumn{1}{|c|}{ Treść orzeczenia kończącego postępowanie karne }} & \multicolumn{2}{c|}{ Mediacje bez ugody } \\
\cline { 2 - 3 } \cline { 2 - 3 } & Liczba & $\%$ \\
\hline Uniewinnienie & 1 & 3,8 \\
\hline Umorzenie & 4 & 15,4 \\
\hline
\end{tabular}

11 W sądach krakowskich wyroki w sprawach, w których osiągnięto ugodę, były nieco bardziej zróżnicowane. Podobnie jak w Białymstoku nie zastosowano ani razu kary bezwzględnego pozbawienia wolności oraz najczęściej orzekano o warunkowym umorzeniu postępowania (58\% spraw), natomiast na drugim miejscu plasowało się umorzenie postępowania (19\%). Karę pozbawienia wolności z warunkowym zawieszeniem zastosowano tylko w $9 \%$ przypadków - zob. M. Chalimoniuk-Zięba, G. Oklejak, Stosowanie postępowania mediacyjnego..., op. cit., s. 329. 
Dariusz Kużelewski

\begin{tabular}{|l|c|c|}
\hline Warunkowe umorzenie & 7 & 27 \\
\hline $\begin{array}{l}\text { Skazanie na karę pozbawienia wolności od 6 miesięcy do 2 lat } \\
\text { w zawieszeniu na określony okres oraz naprawienie szkody lub } \\
\text { zadośćuczynienie }\end{array}$ & 9 & 34,7 \\
\hline Skazanie na karę pozbawienia wolności & 1 & 3,8 \\
\hline Skazanie na karę ograniczenia wolności & 1 & 3,8 \\
\hline Skazanie na karę grzywny & 1 & 3,8 \\
\hline Sprawa w toku & 2 & 7,7 \\
\hline Łącznie & 26 & 100 \\
\hline
\end{tabular}

Źródło: Opracowanie własne.

W sprawach, w których nie doszło do ugody mimo skierowania do mediacji, zróżnicowanie rodzajów orzeczeń kończących postępowanie karne było dużo większe niż w sprawach z mediacjami zakończonymi ugodą. Przeważały wyroki skazujące na karę pozbawienia wolności w zawieszeniu wraz z zobowiązaniem do naprawienia szkody lub zadośćuczynienia oraz wyroki warunkowo umarzające postępowanie karne. Miało miejsce również jedno uniewinnienie w sprawie z oskarżenia subsydiarnego o wyrąb drzewa w lesie celem przywłaszczenia (art. $290 \$ 1$ k.k. w zw. $\mathrm{z}$ art. $278 \$ 1 \mathrm{k} . \mathrm{k}$.), które nastąpiło ze względu na brak danych dostatecznie uzasadniających podejrzenie popełnienia czynu (art. $414 \$ 1$ k.p.k. w zw. z art. $17 \$ 1$ pkt 1 k.p.k. ${ }^{12}$. W jednym z przypadków doszło do skazania bez przeprowadzania rozprawy na wniosek prokuratora złożony w trybie art. $335 \$ 1$ k.p.k. W dwóch kolejnych przypadkach wniosek taki nie został uwzględniony przez sąd.

Tabela 8. Przyczyny niezawarcia ugody w trakcie mediacji

\begin{tabular}{|l|c|c|}
\hline \multicolumn{1}{|c|}{ Przyczyna braku ugody } & Liczba spraw & $\%$ \\
\hline $\begin{array}{l}\text { Niestawiennictwo lub odmowa wzięcia udziału w mediacji przez } \\
\text { oskarżonego/oskarżonych }\end{array}$ & 5 & 19,2 \\
\hline $\begin{array}{l}\text { Niestawiennictwo lub odmowa wzięcia udziału w mediacji przez } \\
\text { pokrzywdzonego/pokrzywdzonych }\end{array}$ & 4 & 15,4 \\
\hline Brak uzgodnienia stanowisk & 16 & 61,6 \\
\hline Zwrot sprawy bez przeprowadzenia mediacji & 1 & 3,8 \\
\hline Łącznie & 26 & 100 \\
\hline
\end{tabular}

Źródło: Opracowanie własne.

12 Podobnie zróżnicowane w przypadku niepowodzenia mediacji były wyroki sądów krakowskich, z tą różnicą, że ilościowo orzekały bardziej równomiernie niż Sąd Rejonowy w Białymstoku. W przedziale od 10 do 18\% wszystkich spraw orzeczono o warunkowym zawieszeniu wykonania kary pozbawienia wolności i grzywny, warunkowym zawieszeniu wykonania kary pozbawienia wolności, warunkowym umorzeniu postępowania karnego, umorzeniu postępowania, uniewinnieniu oraz o karze grzywny. Kara bezwzględnego pozbawienia wolności została orzeczona tylko w jednym przypadku - zob. M. Chalimoniuk-Zięba, G. Oklejak, Stosowanie postępowania mediacyjnego..., op. cit., s. 332. 
Efektywność mediacji w postępowaniach karnych prowadzonych...

Mimo skierowania sprawy do postępowania mediacyjnego, aż w 10 przypadkach (20\% wszystkich badanych spraw) mediacja nie osiągnęła swojego głównego etapu, czyli spotkania oskarżonego z pokrzywdzonym w obecności mediatora. Oskarżeni i pokrzywdzeni mniej więcej w równej liczbie procedur mediacyjnych nie stawiali się albo odmawiali udziału w mediacji. Odejmując powyższe 10 przypadków, okazuje się, że sama sesja mediacyjna z udziałem stron kończy się częściej ugodą niż jej brakiem ( $60 \%$ wobec $40 \%$ w odniesieniu do mediacji, w których doszło do spotkania stron „twarzą w twarz” lub do mediacji pośredniej - jedynie 4 takie przypadki) ${ }^{13}$.

Tabela 9. Liczba spraw a środek odwoławczy

\begin{tabular}{|l|c|c|c|c|c|c|}
\hline \multirow{2}{*}{\multicolumn{1}{|c|}{ Środek odwoławczy }} & \multicolumn{2}{|c|}{$\begin{array}{c}\text { Sprawy skierowane } \\
\text { do mediacji }\end{array}$} & \multicolumn{2}{c|}{$\begin{array}{c}\text { Mediacje zakończone } \\
\text { ugodą }\end{array}$} & \multicolumn{2}{c|}{ Mediacje bez ugody } \\
\cline { 2 - 7 } & liczba & $\%$ & liczba & $\begin{array}{c}\% \text { mediacji } \\
\text { zakończonych } \\
\text { ugoda }\end{array}$ & liczba & $\begin{array}{c}\% \text { me- } \\
\text { diacji bez } \\
\text { ugody }\end{array}$ \\
\hline Wniesiono & 11 & 22 & 3 & 12,5 & 8 & 30,8 \\
\hline Nie wniesiono & 34 & 68 & 20 & 83,3 & 14 & 53,8 \\
\hline $\begin{array}{l}\text { Sprawa w toku w I instancji } \\
\text { w czasie badań aktowych }\end{array}$ & 5 & 10 & 1 & 4,2 & 4 & 15,4 \\
\hline Łącznie & 50 & 100 & 24 & 100 & 26 & 100 \\
\hline
\end{tabular}

Źródło: Opracowanie własne.

Środki odwoławcze wniesiono w 22\% spraw, które wcześniej zostały skierowane do mediacji. Efektywność postępowania mediacyjnego najlepiej obrazują proporcje wniesionych środków odwoławczych do zawartych ugód w trakcie mediacji. Otóż jedynie w 3 przypadkach na 24 sprawy skierowane do mediacji i zakończone ugodą (to jest w 12,5\% takich spraw) wniesiono środek odwoławczy od orzeczenia zapadłego w I instancji. Dwie apelacje zostały wniesione przez obrońców. W tych sprawach Sąd Okręgowy w Białymstoku utrzymał w mocy wyroki sądu I instancji. Trzecia apelacja została wniesiona przez prokuratora, a w jej następstwie wyrok sądu I instancji został zmieniony w ten sposób, że za podstawę prawną warunkowego umorzenia postępowania karnego wobec oskarżonych przyjęto art. $66 \$ 1$ i 2 k.k. oraz art. $67 \S 1$ k.k. w miejsce art. $66 \$ 1$ i 3 k.k. oraz art. $67 \$ 1$ k.k.

Odsetek spraw z mediacją bez ugody, w których wniesiono środek odwoławczy, w stosunku do wszystkich takich spraw wyniósł 30,8\%. Oznacza to, iż niemal trzykrotnie częściej wnoszono środki odwoławcze, gdy postępowanie mediacyjne nie doprowadziło do porozumienia oskarżonego z pokrzywdzonym. Spośród 8 środków

13 Odmiennie kształtowały się przyczyny niezawarcia ugody w sądach krakowskich. Przewagę miały przyczyny formalne, czyli brak zgody na mediację lub niestawiennictwo strony ( $51 \%$ spraw), natomiast mniej licznie wystąpiła rozbieżność stanowisk stron (32\%) - zob. M. Chalimoniuk-Zięba, G. Oklejak, Stosowanie postępowania mediacyjnego..., op. cit., s. 330 . 
odwoławczych wniesionych w tego typu sprawach, w 6 przypadkach apelacja została wniesiona przez obrońców oskarżonych lub przez samych oskarżonych. $\mathrm{W} 5 \mathrm{z}$ nich wyrok został utrzymany w mocy, a apelacja uznana za oczywiście bezzasadną, w jednym zaś przypadku wyrok został zmieniony (w ten sposób, że uchylono rozstrzygnięcie dotyczące orzeczenia solidarnie od oskarżonych na rzecz pokrzywdzonego obowiązku naprawienia szkody w kwocie 100 zł oraz obniżono wysokość orzeczonego solidarnie od oskarżonych na rzecz pokrzywdzonego zadośćuczynienia za doznaną krzywdę do kwoty 10000 zł, w pozostałym zakresie wyrok sądu I instancji utrzymano w mocy). W jednym przypadku apelację złożył zarówno obrońca, jak i pełnomocnik oskarżyciela posiłkowego. Wyrok został jednak utrzymany w mocy, a obie apelacje uznano za oczywiście bezzasadne. Ostatni przypadek był bardziej skomplikowany, gdyż apelacja została wniesiona dwukrotnie od wyroku uniewinniającego przez subsydiarnego oskarżyciela posiłkowego - najpierw Sąd Okręgowy w Białymstoku ów wyrok uchylił i przekazał sprawę do ponownego rozpoznania, następnie po ponownym postępowaniu w I instancji i apelacji wniesionej od kolejnego wyroku uniewinniającego, utrzymał orzeczenie w mocy, a apelację uznał za oczywiście bezzasadną.

Tabela 10. Liczba spraw skierowanych do mediacji przez poszczególnych sędziów i wyniki mediacji

\begin{tabular}{|l|c|c|c|c|c|c|}
\hline \multirow{2}{*}{$\begin{array}{l}\text { Sędzia } \\
\text { (K- kobieta; } \\
\text { M - mężczyzna) }\end{array}$} & \multicolumn{2}{|c|}{$\begin{array}{c}\text { Sprawy skierowane } \\
\text { do mediacji }\end{array}$} & \multicolumn{2}{c|}{$\begin{array}{c}\text { Mediacje zakończone } \\
\text { ugodą }\end{array}$} & \multicolumn{2}{c|}{ Mediacje bez ugody } \\
\cline { 2 - 7 } & liczba & $\%$ & liczba & $\%$ & liczba & $\%$ \\
\hline Nr 1 (M) & 1 & 2 & 1 & 100 & 0 & 0 \\
\hline Nr 2 (K) & 4 & 8 & 1 & 25 & 3 & 75 \\
\hline Nr 3 (M) & 5 & 10 & 2 & 40 & 3 & 60 \\
\hline Nr 4 (M) & 8 & 16 & 6 & 75 & 2 & 25 \\
\hline Nr 5 (K) & 7 & 14 & 2 & 28,6 & 5 & 71,4 \\
\hline Nr 6 (K) & 13 & 26 & 7 & 53,8 & 6 & 46,2 \\
\hline Nr 7 (K) & 10 & 20 & 4 & 40 & 6 & 60 \\
\hline Nr 8 (K) & 2 & 4 & 1 & 50 & 1 & 50 \\
\hline Łącznie & 50 & 100 & 24 & 48 & 26 & 52 \\
\hline
\end{tabular}

Źródło: Opracowanie własne.

W badanym okresie sprawy do postępowania mediacyjnego kierowało 8 sędziów, z których najaktywniejsze w tym zakresie były sędzie nr 6 i 7 (łącznie 46\% przypadków). Nie można oczywiście wyciągać zbyt daleko idących wniosków co do przyczyn zobrazowanych $w$ tabeli 10 . różnic $w$ liczbie kierowanych spraw przez po- 
Efektywność mediacji w postępowaniach karnych prowadzonych...

szczególnych sędziów. Wpływ na to ma bowiem nie tylko specyfika każdej sprawy i wola stron, ale również łączna liczba spraw prowadzonych w tym czasie przez każdego sędziego, a ta zależna może być od wielu czynników. Tym bardziej nie można wyciągać wniosków co do statystyk związanych ze skutecznością mediacji, gdyż nawet wybór określonego mediatora nie gwarantuje sukcesu.

Tabela 11. Mediatorzy powoływani przez poszczególnych sędziów

\begin{tabular}{|c|c|c|c|c|c|c|c|}
\hline \multirow{2}{*}{$\begin{array}{l}\text { Sędzia } \\
\text { (K - kobieta; } \\
\text { M - mężczyzna) }\end{array}$} & \multicolumn{6}{|c|}{ Mediator (K - kobieta; M - mężczyzna) } & \multirow{2}{*}{ Łącznie } \\
\hline & $\operatorname{Nr} 1(\mathrm{~K})$ & $\mathrm{Nr} 2(\mathrm{M})$ & $\mathrm{Nr} 3(\mathrm{M})$ & $\mathrm{Nr} 4(\mathrm{M})$ & $\operatorname{Nr} 5(\mathrm{~K})$ & $\mathrm{Nr} 6(\mathrm{~K})$ & \\
\hline $\mathrm{Nr} 1$ (M) & 0 & 0 & 1 & 0 & 0 & 0 & 1 \\
\hline $\mathrm{Nr} 2(\mathrm{~K})$ & 0 & 0 & 0 & 0 & 2 & 2 & 4 \\
\hline $\operatorname{Nr} 3(\mathrm{M})$ & 0 & 0 & 5 & 0 & 0 & 0 & 5 \\
\hline $\mathrm{Nr} 4(\mathrm{M})$ & 0 & 2 & 2 & 1 & 3 & 0 & 8 \\
\hline $\operatorname{Nr} 5(\mathrm{~K})$ & 0 & 1 & 2 & 0 & 2 & 2 & 7 \\
\hline $\operatorname{Nr} 6(\mathrm{~K})$ & 1 & 0 & 0 & 0 & 2 & 10 & 13 \\
\hline $\operatorname{Nr} 7(\mathrm{~K})$ & 0 & 0 & 0 & 0 & 2 & 8 & 10 \\
\hline $\operatorname{Nr} 8(\mathrm{~K})$ & 0 & 0 & 1 & 0 & 1 & 0 & 2 \\
\hline Łącznie & 1 & 3 & 11 & 1 & 12 & 22 & 50 \\
\hline
\end{tabular}

Źródło: Opracowanie własne.

Dane zamieszczone w tabeli 11. nie służą ocenie efektywności postępowań mediacyjnych, wskazują natomiast, czy sędziowie mają swoich niejako „stałych” czy „ulubionych” mediatorów, czy też starają się dywersyfikować osoby, którym powierzają zadanie przeprowadzenia mediacji. Troje sędziów (nr 3, 6 i 7) miało zdecydowanie ugruntowane preferencje, zlecając prowadzenie mediacji w większości temu samemu mediatorowi. Mediatorka nr 6 otrzymała 18 spraw z 22 właśnie od sędzi nr 6 i sędzi nr 7. Za ciekawostkę należy uznać, że sędziowie płci męskiej znacznie chętniej powołują mediatorów mężczyzn (w 10 na 14 przypadków, tj. w 71,4\%), zaś panie desygnują głównie kobiety mediatorki (w 32 na 36 przypadków, tj. w 88,9\% przypadków). Jedynie sędzia nr 4 oraz sędzia nr 5 przekazywali sprawy do mediacji 4 mediatorom z 6 powoływanych do prowadzenia postępowań mediacyjnych w okresie objętym badaniami. 
Tabela 12. Liczba przeprowadzonych mediacji przez poszczególnych mediatorów i ich wyniki

\begin{tabular}{|l|c|c|c|c|c|c|c|c|}
\hline \multirow{2}{*}{$\begin{array}{l}\text { Mediator (K } \\
\text { - kobieta; }\end{array}$} & $\begin{array}{c}\text { Sprawy skie- } \\
\text { M-męż- } \\
\text { czyzna) } \\
\text { mediacji }\end{array}$ & \multicolumn{4}{|c|}{ Mediacje zakończone ugodą } & \multicolumn{3}{|c|}{ Mediacje bez ugody } \\
\cline { 2 - 9 } & Liczba & $\%$ & Liczba & $\begin{array}{c}\text { \% mediacji } \\
\text { danego } \\
\text { mediatora }\end{array}$ & $\begin{array}{c}\% \text { mediacji } \\
\text { zakończo- } \\
\text { nych ugodą }\end{array}$ & Liczba & $\begin{array}{c}\% \text { mediacji } \\
\text { danego } \\
\text { mediatora }\end{array}$ & $\begin{array}{c}\% \text { me- } \\
\text { diacji bez } \\
\text { ugody }\end{array}$ \\
\hline Nr 1 (K) & 1 & 2 & 0 & 0 & 0 & 1 & 100 & 3,8 \\
\hline Nr 2 (M) & 3 & 6 & 1 & 33,3 & 4,2 & 2 & 66,6 & 7,7 \\
\hline Nr 3 (M) & 11 & 22 & 6 & 54,5 & 25 & 5 & 45,5 & 19,3 \\
\hline Nr 4 (M) & 1 & 2 & 0 & 0 & 0 & 1 & 100 & 3,8 \\
\hline Nr 5 (K) & 12 & 24 & 6 & 50 & 25 & 6 & 50 & 23,1 \\
\hline Nr 6 (K) & 22 & 44 & 11 & 50 & 45,8 & 11 & 50 & 42,3 \\
\hline Łącznie & 50 & 100 & 24 & - & 100 & 26 & - & 100 \\
\hline
\end{tabular}

Źródło: Opracowanie własne.

Jak wskazano wyżej, mediacje w omawianym okresie prowadziło 6 mediatorów, przy czym połowa $\mathrm{z}$ nich była powoływana w 45 przypadkach ( $90 \%$ wszystkich mediacji ${ }^{14}$. Mimo równego rozkładu płci, mediatorki otrzymały 35 spraw (70\%). Wśród trójki liderów pod względem liczby przeprowadzonych mediacji współczynnik sukcesu - mierzony liczbą ugód w stosunku do wszystkich mediacji danego mediatora - wyniósł 50\% z niewielkim odchyleniem na korzyść w przypadku mediatora nr 3.

$\mathrm{Z}$ zaprezentowanych wyników badań aktowych można wysnuć następujące wnioski:

- mimo iż Sąd Rejonowy w Białymstoku plasuje się nieco powyżej średniej liczby spraw przypadającej statystycznie na jeden sąd (łącznie rejonowe i okręgowe) w Polsce, jednak pod względem efektywności mediacji mierzonej współczynnikiem mediacji, w których zawarto ugody do wszystkich spraw skierowanych do mediacji, wypada na tle średniej ogólnopolskiej dużo słabiej (współczynnik ten w każdym z badanych lat jest o około 10-30\% niższy),

- jedynie 26\% spraw, w których skierowano sprawę do mediacji, toczyło się w trybie prywatnoskargowym, a współczynnik osiągniętych ugód był tu najniższy ze wszystkich trybów $(30,8 \%)$, co stoi w sprzeczności z silnie wyeksponowaną w k.p.k. ideą ugodowego załatwiania tego typu spraw,

14 Nierównomierny rozkład spraw między mediatorów w Sądzie Rejonowym w Białymstoku nie jest niczym nadzwyczajnym, zważywszy na przykład sądów krakowskich, gdzie jeden mediator (z grona 74 osób i jednej instytucji) „zmonopolizował” usługi mediacyjne, gdyż w ciągu dwóch lat był powoływany do prowadzenia mediacji w 338 przypadkach na 383 sprawy, osiągając przy tym 80\% skuteczność w doprowadzaniu do ugody i nigdy nie zwracając się o przedłużenie terminu zakończenia postępowania mediacyjnego - M. Chalimoniuk-Zięba, G. Oklejak, Stosowanie postępowania mediacyjnego..., op. cit., s. 325-326. 
- rodzaje przestępstw stanowiących najczęściej przedmiot postępowania mediacyjnego w Sądzie Okręgowym w Białymstoku nie odbiegają od tego typu spraw w innych sądach - są to najczęściej przestępstwa przeciwko życiu i zdrowiu, czci i nietykalności cielesnej, rodzinie i opiece, mieniu, wolności,

- o przeprowadzenie postępowania mediacyjnego najczęściej wnioskują obrońcy oraz sami oskarżeni, a w dalszej kolejności sąd, natomiast najlepszy skutek w postaci ugody mediacja osiąga $\mathrm{w}$ razie wspólnej inicjatywy stron; całkowitym fiaskiem kończyła się inicjatywa pokrzywdzonego oraz jego pełnomocnika, gdyż żadna z mediacji nie zakończyła się ugodą,

- znaczna większość mediacji (72\%) toczy się z udziałem jednego oskarżonego i jednego pokrzywdzonego,

- żadna ze spraw, w której zawarto ugodę, nie zakończyła się skazaniem na bezwzględne pozbawienie wolności - w większości przypadków sąd zastosował warunkowe umorzenie postępowania lub karę pozbawienia wolności z zawieszeniem jej wykonania; z kolei w przypadku spraw niezakończonych ugodą rozstrzygnięcia sądu były bardziej zróżnicowane, niemniej najczęściej (w $1 / 3$ spraw) były to wyroki skazujące na karę pozbawienia wolności z zawieszeniem jej wykonania oraz warunkowe umorzenie postępowania; stosunkowo rzadko ugody skutkowały dobrowolnym poddaniem się karze,

- najczęstszą przyczyną nieosiągnięcia ugody był brak uzgodnienia stanowisk (61,6\% przypadków), a w dalszej kolejności niestawiennictwo bądź odmowa wzięcia udziału w mediacji przez oskarżonych lub pokrzywdzonych,

- mediacja zakończona ugodą skutecznie powstrzymuje od składania środków odwoławczych od orzeczenia kończącego sprawę w I instancji, jedynie w $12,5 \%$ spraw wniesiono apelację; niemal wszystkie apelacje - zarówno w przypadku zawarcia ugody, jak i jej braku - nie przyniosły skutku i sąd odwoławczy utrzymywał wyroki, uznając apelacje za oczywiście bezzasadne,

- poszczególni sędziowie $\mathrm{w}$ prowadzonych przez siebie sprawach powoływali na mediatorów na ogół tę samą osobę, przypadki „dywersyfikacji” mediatorów były rzadsze.

Obecnie w sądzie rejonowym w sprawach karnych ze względu na niewystępowanie przed sądem przedstawicieli społecznych oraz ławników, udział mediatorów jest najważniejszym przejawem obecności i aktywnej roli czynnika społecznego w procesie karnym. Warty podkreślenia jest wniosek wynikający z wywiadów przeprowadzonych z praktykami wymiaru sprawiedliwości i organów ścigania, jak też kuratorami sądowymi, że praktycy widzą potencjał i odnoszą się z dużym zainteresowaniem do zastosowania $\mathrm{w}$ polskim procesie karnym elementów modelu Community Court. W obecnych realiach centralną rolę, ich zdaniem, powinna zajmować mediacja między ofiarą a sprawcą. 


\section{Bibliografia}

Bieńkowska E., O unormowaniu mediacji w sprawach karnych, „Prokuratura i Prawo” 2012, nr 1.

Chalimoniuk-Zięba M., Oklejak G., Stosowanie postępowania mediacyjnego w sprawach karnych w latach 2010-2011, analiza na podstawie badań aktowych przeprowadzonych w krakowskich sądach rejonowych, (w:) J. Czapska, M. Szeląg-Dylewski (red.), Mediacje w prawie, Kraków 2014.

Kaszczyszyn R., Rozwój i sytuacja mediacji w Polsce na przykładzie ośrodka lubelskiego, „Mediator” 2003 , nr 2.

Kużelewski D., Mediacja w polskim procesie karnym w ocenie prokuratorów i sędziów, (w:) C. Kulesza (red.), Porozumienia karnoprocesowe w praktyce wymiaru sprawiedliwości, Białystok 2010.

Kużelewski D., Mediacja w procesie karnym w opinii sędziów i prokuratorów - wybrane zagadnienia, (w:) C. Kulesza (red.), Ocena funkcjonowania porozumień procesowych w praktyce wymiaru sprawiedliwości, Warszawa 2009.

Mazowiecka L. (red.), Mediacja karna jako forma sprawiedliwości naprawczej, Warszawa 2011.

Mazowiecka L. (red.), Mediacja karna jako instytucja ważna dla pokrzywdzonego, Warszawa 2013.

Mazowiecka L. (red.), Mediacja w praktyce prokuratorskiej - dziś i jutro, Warszawa 2012.

Mazowiecka L. (red.), Unijne standardy programów sprawiedliwości naprawczej, Warszawa 2015.

Mendelska-Stec M., Wyniki badań. Funkcjonowanie instytucji mediacji w Polsce, „Mediator” 2005, nr 3.

Pawlak H., Mediacja w świetle danych Ministerstwa Sprawiedliwości, (w:) Konferencja naukowa: „Mediacja w polskiej rzeczywistości" (11 września 2002 r.), Warszawa 2003.

Skrobotowicz G.A., Mediacja karna - studium przypadku, (w:) J. Czapska, M. Szeląg-Dylewski (red.), Mediacje w prawie, Kraków 2014.

Szumiło-Kulczycka D., Proces karny a idea sprawiedliwości naprawczej, (w:) P. Hofmański (red.), System prawa karnego procesowego, t. I, Zagadnienia ogólne, cz. 2, Warszawa 2014.

Wildner E., Stosowanie mediacji w postępowaniu przygotowawczym - wybrane zagadnienia, (w:) J. Czapska, M. Szeląg-Dylewski (red.), Mediacje w prawie, Kraków 2014.

Wójcik D., Poglądy sędziów na temat mediacji w sprawach karnych, (w:) K. Krajewski (red.), Nauki penalne wobec problemów współczesnej przestępczości. Księga jubileuszowa z okazji 70. rocznicy urodzin Profesora Andrzeja Gaberle, Warszawa - Kraków 2007. 